\title{
«He elegido tener en ti mi morada» Inhabitación mística en los escritos de santa Gertrudis de Helfta
}

\author{
Ana Laura Forastieri, OCSO• \\ Monasterio Madre de Cristo \\ s.analaura.ocso@gmail.com \\ Nora Beatriz Rodríguez OCV •• \\ norabeatrix@gmail.com \\ Recibido 05.10.2020/Aprobado 04.01.2021 \\ DOI: https://doi.org/10.46553/teo.58.134.2021.p151-168
}

\section{RESUMEN:}

La conciencia de la presencia permanente de Jesús en su corazón es el rasgo peculiar de la espiritualidad mística de santa Gertrudis de Helfta. Este tema ha sido receptado en la oración propia de su fiesta y también en la iconografía, que representa a santa Gertrudis con su corazón expuesto, conteniendo al niño Jesús. Las raíces de esta espiritualidad ya se encuentran en la tradición monástica antigua, aunque reciben mayor desarrollo y un enfoque nupcial en la doctrina de san Bernardo. Santa Gertrudis se nutre de estas fuentes tradicionales pero les da una expresión propia, mediante un lenguaje dialogal, que pone en juego una dinámica continua de donación y acogida, búsqueda y encuentro, deseo y unión. Así, de sus escritos surge una teología metafórica en clave relacional y nupcial. En este trabajo enfocamos los temas de la visita y la morada, como imágenes principales de la acogida de Cristo como huésped; abordamos también el encuentro místico y la comunión, como hospitalidad recíproca. Concluimos con una reflexión sobre la vigencia de esta mirada y de este lenguaje para la construcción de una cultura del

- Ana Laura Forastieri es monja trapense en el Monasterio Madre de Cristo (Hinojo, Argentina); cursa actualmente la licenciatura en teología con especialización en dogmática en la Pontificia Universidad Católica Argentina; colabora, desde el año 2012, con la causa de postulación de Santa Gertrudis como doctora de la Iglesia.

• Nora Beatriz Rodríguez, virgen consagrada de la Arquidiócesis de Buenos Aires, es Profesora en Letras. 
encuentro y de la acogida del otro, que tenga como estilo distintivo la hospitalidad y la inclusión.

Palabras clave: Mística; Visita; Morada; Matrimonio espiritual

«I Have Chosen to Abide in You».

\section{Mystical Dwelling in the Writings of Saint Gertrude of Helfta}

ABSTRACT:

The awareness of Jesus ongoing presence to the heart is the peculiar feature of St. Gertrude of Helfta's mystic spirituality. This subject has been receipted in the prayer of her feast, and in the iconography, which features St. Gertrude with her exposed heart and Jesus Child within. The roots of this spirituality are already found in the ancient monastic tradition, though they received a greater development and a nuptial focus with St. Bernard's writings. St. Gertrude draws on this traditional sources, but she also gives them her own expression through a dialogic language, which puts into play a continuous dynamic of self-donation and reception, search and encounter, desire and union. Thus, a metaphorical theology arises from her writings, in a relational and nuptial key. This work focuses mainly on: 'visit' and 'dwelling', as principal images of welcoming Christ as a guest; it also treats about mystical encounter and communion, as reciprocal hospitality. The paper concludes with a reflection on the opportunity of this approach and language to build up an encountering and welcoming culture, whose distinctive style is hospitality and inclusion.

Keywords: Mystical; Spiritual Visitation; Spiritual Dwelling; Spiritual Marriage

La colecta propia de la fiesta de Santa Gertrudis, reza así: «Dios nuestro, que habitaste con agrado en el corazón de santa Gertrudis, virgen, disipa, por sus ruegos, las tinieblas de nuestro corazón, para que podamos experimentar con alegría tu presencia y tu acción en nosotros». ${ }^{1}$ Con esta oración, la Liturgia señala como rasgo peculiar de la espiritualidad de esta mística medieval, la experiencia de la presencia permanente de Jesús en su corazón, y pide esta gracia para nosotros. Este motivo caracteriza también la iconografía de santa Gertrudis, que habitualmente la representa con el corazón expuesto, conteniendo al Niño Jesús. Se trata de un tema

1 Misal Romano, oración colecta de la fiesta de Santa Gertrudis, virgen, 16 de noviembre; en: Conferencia Episcopal Argentina, ed., Misal Romano Cotidiano. Versión castellana de la $3^{a}$ edición típica latina y los Leccionarios I-IV (Buenos Aires: Conferencia Episcopal Argentina, Oficina del Libro, 201 1, 2276. En Argentina, la fiesta de Santa Gertrudis se celebra con carácter de memoria libre, el 16 de noviembre, debido a que el 17 de noviembre prima la memoria obligatoria de San Roque González y compañeros mártires rioplatenses 
monástico tradicional: el cultivo del sentido de la presencia de Dios por medio de la memoria Dei y la intentio cordis u oración de deseo.

El Monacato surgió como intento de poner en práctica la exhortación apostólica de orar sin cesar; ${ }^{2}$ pero pronto los antiguos monjes se dieron cuenta que no era posible cumplir este precepto literalmente. El Monacato cultivó así distintos medios ascéticos y espirituales para concentrar la atención del corazón en la presencia continua de Dios: el silencio, la salmodia, la vigilancia, el combate contra los pensamientos apasionados, la oración jaculatoria, la repetición del nombre del Señor o de versículos de la Sagrada Escritura, el recuerdo de Dios a lo largo del día. Pero no fue sino hasta los escritos de san Bernardo, que esta tradición adquirió una expresión nupcial: es decir, que la práctica de la atención continua a la presencia de Dios se expresó como búsqueda del encuentro del monje o de la monja con Cristo Esposo, por el deseo. El enfoque esponsal, sin embargo, no es original de san Bernardo: éste lo tomó de Orígenes y de san Agustín, ya sea directamente o a través de la pluma de san Gregorio Magno. Pero fue principalmente san Bernardo quien aplicó la perspectiva nupcial a la vida monástica, re-expresando los medios ascéticos y espirituales de la oración continua en clave de búsqueda de la unión esponsal con Cristo.

Santa Gertrudis se nutre de estas fuentes tradicionales -principalmente de los escritos de san Bernardo-, pero les da una expresión propia, mediante un lenguaje dialogal, que pone en juego una dinámica continua de donación y acogida, búsqueda y encuentro, deseo y unión con el Señor. Así, de sus escritos, ${ }^{3}$ surge una teología

2 Cf. 1 Ts $5,17$.

3 La edición crítica latina de las obras completas de santa Gertrudis es: Gertrude D’ Helfta, Oeuvres Spirituelles, Tomo I, Les Exercices, Sources Chrétiennes N 127 (Paris: Du Cerf, 1967); Tomo II: Le Héraut Livres let II, Sources Chrétiennes N 139 (Paris: Du Cerf, 1968); Tomo III: Le Héraut Livre III, Sources Chrétiennes 143, (Paris: Du Cerf, 1968); Tomo IV: Le Héraut Livre IV, Sources Chrétiennes 255 (Paris: Du Cerf, 1978); Tomo V: Le Héraut Livre V, Sources Chertiénnes 331 (París: Du Cerf, 1986). En este trabajo los textos se citan según la siguiente edición en casteIlano: Santa Gertrudis de Helfta, Los Ejercicios (Burgos: Monte Carmelo, 2003); Id., El Mensajero 
metafórica en clave relacional y nupcial, por la cual ella traduce el ideal de la atención continua a la presencia de Dios, propio del Monacato, como morada permanente de Cristo Esposo al interior del creyente, lo que equivale a la unión esponsal estable. En este trabajo enfocamos especialmente los temas de la visita y la morada, como imágenes principales de la acogida de Cristo como huésped; abordamos también el encuentro místico y la comunión, como hospitalidad recíproca. Concluimos con una reflexión sobre la vigencia de este enfoque y de este lenguaje para la construcción de una cultura del encuentro y de la acogida del otro, que tenga como estilo distintivo la hospitalidad y la inclusión.

\section{Las Visitas}

«Cuántas veces ... me hiciste sentir de diversas maneras el gusto de tu saludable presencia! ¡Con qué bendiciones de dulzura prevenías de modo constante mi pequeñez, en aquellos tres primeros años, y mucho más especialmente al ser admitida a participar en la recepción de tu bendito Cuerpo y Sangre! ${ }^{4}$

Con esta exclamación de agradecimiento Gertrudis nos introduce en lo íntimo de su experiencia, en los tres primeros años que siguieron a su conversión. Su vida mística comenzó en 1281, con una visión de Jesús en la forma de un joven adolescente, que la sacó de su crisis de angustia y turbación, prometiéndole la paz y el deleite espiritual. Esta visita introdujo a Gertrudis en el conocimiento de sí misma:

de la Ternura Divina. Experiencia de una mistica del siglo XIII, Tomo I: Libros 1-3; e Ibid., Tomo II: Libros 4-5 (Burgos: Monte Carmelo, 2013).

4 Santa Gertrudis de Helfta, Legatus Divinae Pietatis, Libro II, capítulo 22, parágrafo 1 (en adelante se citará: L, seguido de número romano para indicar el Libro, y número arábigo para indicar sucesivamente el capítulo y el parágrafo. Aquí: L II 9,1); en: Santa Gertrudis de Helfta, El Mensajero... Tomo I (en adelante MTD I), 160. El Legatus Divinae Pietatis (El Heraldo o El Mensajero, según las traducciones) es la obra de recopilación sobre la vida de Gertrudis. Consta de cinco libros, de los cuáles solo el Libro II fue escrito de puño y letra por Gertrudis; los restantes libros son la recopilación de los recuerdos transmitidos por la santa a otra monja anónima de la comunidad, conocida como la Redactrix. 
«Entonces caí en la cuenta de todo lo que en mi corazón había ofendido a la extrema delicadeza de tu pureza: tanto desorden, tanta confusión, sin intención de ofrecer una morada a tu deseo. Sin embargo, ni esto ni mi vileza, te impidió, amantísimo Jesús, que, con frecuencia, los días que me acercaba al alimento vivificante de tu Cuerpo y de tu Sangre, te dignaras favorecerme con tu presencia visible». ${ }^{5}$

A partir de «la primera visita del Señor» ${ }^{6}$-hecho que señala su conversión- se suceden otras varias visitas, en un breve e intenso período de tiempo. Esto mueve a Gertrudis a:

«Agradecer el gustosísimo don de tu visita, que recibí de forma tan gratuita de tu inconmensurable generosidad, y he guardado durante tantos años, sin mérito mío alguno. Porque, aunque sea la más indigna de todas las criaturas, confieso, sin embargo, que en este don recibí una gracia mayor que la que jamás puede merecer hombre alguno en esta vida». ${ }^{7}$

Por medio de estas frecuentes visitas el Señor va educando a Gertrudis de distintas maneras, para concederle muy pronto la gracia de establecer, en el corazón de ella, su morada permanente. Esta gracia le será dada dentro del primer año de su conversión y ya no la abandonará jamás: «Al principio me concediste la gracia que no merecía [la conversión], y a pesar de ser más grave recaer que caer por primera vez, te dignaste concederme, sin mérito propio, la alegría de tu saludable presencia, que permanece hasta el presente». ${ }^{8}$

«Para esta comunicación de ternura me visitabas a distintas horas y de modos diversos, pero de modo especial y con más benignidad en la vigilia de la santa Anunciación. Finalmente, cierto día antes de la Ascensión, esta presencia fue más afectuosa; comenzaste por la mañana y la realizaste plenamente por la tarde, después de Completas. Me concediste este don maravilloso, digno de ser venerado por todas las criaturas, a saber, que, desde aquella hora hasta el momento presente, nunca he sentido o experimentado que te separaras de mi corazón ni por un pestañear de ojos, antes bien, siempre he sentido que estabas presente, cada vez que volvía a mi interior, excepto una vez por espacio de once días». ${ }^{9}$

5 ld., L II 2,1; en MTD I, 137.

6 lbid., 1,1; en MTD I, 134.

7 lbid., 22, 1; en MTD I, 198.

8 lbid., 3,3; en MTD I, 141-142.

9 lbid., 23,6; en MTD I, 203. 
De estos textos surge la distinción entre la gracia de visita y la gracia de la morada o habitación permanente de Cristo en su corazón. La visita es una experiencia puntual, circunscripta en el tiempo, que queda en la memoria y que produce un fruto espiritual preciso y constatable en el alma. Puede tener diversos propósitos: llevar a Gertrudis al conocimiento humilde de sí misma, provocar su enmienda y corrección, hacerle experimentar y gozar de la unión divina, instruirla en las cosas de Dios. Veamos algunos textos:

«No sabré expresar por escrito cómo me visitaste, joh Luz que vienes de lo alto!, con las entrañas de tu misericordia... Al reparar cómo era mi vida tanto antes como después, confieso con toda sinceridad que fue una gracia totalmente gratuita e inmerecida. Desde ese instante me regalabas una luz tan viva de tu conocimiento, que el dulce amor de tu amistad me estimulaba con más fuerza que el castigo merecido de tu severidad, para moverme a la enmienda. No recuerdo haber tenido tal fruición fuera de aquellos días en los que me invitabas a las delicias de tu regia mesa». ${ }^{10}$

«Mi alma ... experimentaba contener a su Amado metido en lo más profundo de su ser y gozaba con dulcísima ternura, sin que se apartara de ella, la amorosísima presencia del Esposo». ${ }^{11}$

«Purificada de toda deshonra de los pecados y suplida en mí toda carencia de méritos ..., merecía gozar de tus castos abrazos, en tu ansiada y dulcísima presencia, de la que en mí soy indigna, pero en ti, dignísima». ${ }^{12}$

La visita no es una gracia permanente, sino puntual y pasajera. Aunque Gertrudis la recibe frecuentemente, a veces también siente su falta:

«Postrada en el lecho, en la sacrosanta fiesta de la Purificación, por una grave enfermedad, entristecida en mi corazón, me quejaba, al amanecer, por no poder recibir la visita divina, con la que solía ser frecuentemente consolada en ese día). ${ }^{13}$ 
A veces también el Señor la visita para descansar en ella y pedirle su oración y penitencia por la conversión de los pecadores:

«En cierta ocasión antes de Cuaresma, el domingo que se canta de entrada "Sé para mí", ${ }^{\prime 4}$ me diste a entender con las palabras de este canto, que pedías la morada de mi corazón para descansar en él, tras haber sido atormentado y perseguido por la multitud. Cada vez que, los tres días siguientes, entraba en mi corazón, te veía reposar en mi pecho como enfermo agotado. Durante esos tres días, nada encontraba que pudiera ofrecerte mejor alimento, que entregarme por tu amor a la oración, al silencio, a la mortificación, por la conversión de las personas mundanas». ${ }^{15}$

Aún después de recibida la gracia de inhabitación permanente, Gertrudis continúa recibiendo las visitas del Señor, como momentos de especial intensidad que renuevan en ella la conciencia de la presencia divina o la sacuden de su inercia, moviéndola a la alabanza o a la enmienda de sus faltas:

"Cierta tarde tuve un arrebato de ira. A la mañana siguiente, antes del amanecer, tuve un momento oportuno para orar. Te presentaste ante mí en forma de un pordiosero que, por el aspecto, pensaba carecías de fuerzas y de todo recurso humano. Entonces comenzó a remorderme la conciencia por la falta del día anterior ... Juzgué entonces y deliberé que lo mejor sería que te alejaras de mi alma, en lugar de estar presente: al menos en los momentos que me mostraba perezosa en rechazar al enemigo, cuando me incitaba a cosas tan contrarias a ti ... Recibí la siguiente respuesta tuya: "... Puesto que he elegido, vencido por tu amor, tener mi morada en ti, entre todas las tormentas de los vicios que te inundan, intento alcanzar la serenidad de tu enmienda y el puerto de la humildad». ${ }^{16}$

En los pasajes citados, Gertrudis demuestra conocer y haber asimilado la doctrina de san Bernardo, hasta poder reexpresarla desde su propia experiencia personal. San Bernardo aplica la imagen de las visitas del Verbo al alma creyente, para describir la alternancia de la vida espiritual, en la que se suceden momentos de búsqueda y

14 Es decir, el introito «Esto mihis (cf. Sal 30, 3-4). Es el domingo anterior al inicio de la Cuaresma; actualmente, el domingo VI del tiempo ordinario; cf. Conferencia Episcopal Argentina, ed., Misal Romano... 380.

15 Santa Gertrudis, L II 14,1: en MTD I, 173

16 lbid., 12,2; en MTD I, 169-170. 
encuentro, presencia y ausencia, consolación y desolación: «Es cosa clara -dice san Bernardo- que en el alma acontecen estas alternancias del Verbo, que se va y que vuelve, como él mismo dice: "Voy y vuelvo a vosotros"; 17 y también: " Dentro de poco ya no me veréis, y dentro de otro poco me volveréis a $v^{\prime \prime}{ }^{\prime \prime 18}{ }_{\gg .}{ }^{19}$

«El Verbo de Dios, Dios, el Esposo del alma, según le parece a él, tan pronto viene al alma como de nuevo la abandona ... Por ejemplo, cuando el alma siente la gracia, conoce su presencia; cuando no la siente, se lamenta de su ausencia, y de nuevo busca la presencia ... ¿Por qué lo busca? Porque, cuando tan dulce Esposo se ha alejado de ella, no le es posible desear otra cosa, y ni siquiera pensarla. La única solución que le queda es buscar con afán al ausente, y llamar al que se aleja ... con el deseo del alma». ${ }^{20}$

"Cuando se hace presente el que ha sido buscado con vigilias y súplicas y con lluvia de lágrimas, de repente, cuando creía que ya era suyo, se escapa; y de nuevo viene al encuentro del que llora y va en pos de él y se deja abrazar por él, pero no retener; mientras que, otra vez, de súbito, se le escapa de las manos. Pero, si el alma devota insiste con oraciones y lágrimas, volverá de nuevo y no le negará lo que piden sus labios, ${ }^{21}$ mas de nuevo desaparecerá y dejará de verse, a no ser que nuevamente sea buscado con todo deseo. Así pues, también mientras se vive en este cuerpo puede existir gozo frecuente a causa de la presencia del Esposo, pero no será grande, porque, aunque su visita causa alegría, al volverse a marchar causa tristeza ... Sin embargo, ni siquiera de pasada se hace presente así a todas las almas; solamente a aquella a la que la gran devoción, el deseo vehemente y el muy dulce afecto, pone de manifiesto que es una esposa digna, a la que el Verbo vestido de hermosura, tomando la forma de Esposo, se acercará con la gracia de su visita». ${ }^{22}$

Así, según san Bernardo, el alma creyente busca a Dios por el deseo; y sólo la que lo busca con un deseo vehemente, y está dispuesta a dejar todas las cosas por correr tras el Verbo, puede ser llamada Esposa. Esta es la que merece la gracia de las visitas:

17 Cf. Jn 14,28 .

$18 \mathrm{Cf}$. Jn 15,17 .

19 San Bernardo de Claraval, Super Cantica Canticorum, Sermón 74,4 (en adelante: SC, seguido de número de sermón y parágrafo). La versión en castellano está tomada de: Id., Sermones sobre el Cantar de los Cantares. Intr. y tr. J.L. Santos Gómez, OCSO (Madrid: Monasterio de Sta. María de Oseira ed., 2000), 467.

20 San Bernardo, SC 74,2; en Id., Sermones sobre el Cantar.. 466.

21 Cf. Sal 20,2.

22 San Bernardo, SC 32,2 y 3; en: Id., Sermones sobre el Cantar.. 226-227. 
«Dame ahora un alma a la que el Verbo Esposo acostumbre a visitar con frecuencia, a la que la familiaridad le haya dado atrevimiento; el haberlo saboreado, hambre; y el desprecio de todas las cosas, ocio santo; y yo, sin duda alguna, le asignaré el título y el nombre de Esposa». ${ }^{23}$

La noción de visitas en san Bernardo abarca una variada gama de experiencias espirituales. El Verbo visita al alma con diversos fines: para consolarla, para reprenderla, para purificarla, para instruirla, para unirla a Sí:

«Y no se hará presente de esta manera de una manera continua, ni siquiera a los espíritus devotísimos, ni se aparece de la misma manera a todos. Es conveniente que el gusto de la divina presencia varíe conforme a los diversos deseos del alma, y que el sabor infuso de la dulzura celestial, deleite de diferente manera el paladar del alma anhelante). ${ }^{24}$

«Confieso que también el Verbo -lo digo disparatando- ${ }^{25}$ ha venido hacia mí, y muchas veces. Y aunque con frecuencia ha entrado en mí, algunas veces no lo sentí en el momento de entrar. Sentí que se había hecho presente, y recuerdo el momento de ausentarse. Alguna vez pude incluso presentir su llegada, pero sentirla nunca; tampoco he sentido nunca su salida». ${ }^{26}$

«¿Quieres saber, entonces, cómo es que, siendo sus caminos totalmente irrastreables, ${ }^{27}$ yo me doy cuenta de que está presente? Es vivo y enérgi$\mathrm{Co}^{28}$ y nada más venir a mi interior, despertó mi alma adormecida; movió, ablandó e hirió mi corazón, ${ }_{t}^{29}$ porque era duro, ${ }^{30}$ de piedra ${ }^{31}$ y malsano. También empezó a arrancar y destruir, edificar y plantar;, a regar lo árido, a iluminar lo oscuro, a abrir lo que estaba cerrado, a incendiar lo que estaba frío, y también a enderezar lo torcido y a igualar lo escabroso. ${ }^{33}$ Hizo todo esto con el fin de que mi alma bendijese al Señor y todo mi ser a su santo nombre. ${ }^{34}$ Entrando así algunas veces en mí el Verbo Esposo, nunca hizo reconocible su entrada por huella alguna: ni por la voz, ni por la figura, ni por

23 ld., SC 74,3; en: Ibid., 467.

24 lbid., 31,7 ; en: ld., 223.

25 Cf. 2 Co $11,17$.

26 San Bernardo, SC 74,5; en: Id., Sermones sobre el Cantar... 468.

27 Cf. Rm $11,33$.

$28 \mathrm{Cf}$. Hb 4, 12 .

29 Cf. Ct 4,9 .

$30 \mathrm{Cf}$. Qo 3,27 .

$31 \mathrm{Cf}$. Ez 11,19;36,26.

32 Cf. Jr $1,10$.

$33 \mathrm{Cf}$. Is 40,4 .

34 Cf. Sal 102,1 
los pasos. En una palabra, no lo descubrí por ninguno de sus movimientos, ni se deslizó a través de alguno de mis sentidos más profundos: como os he dicho, sólo conocí su presencia por el movimiento de mi corazón. También advertí el poder de su fuerza ${ }^{35}$ por la huida de los vicios y la desaparición de los afectos carnales; por el descubrimiento y acusación de mis pecados ocultos, ${ }_{r}^{36}$ me admiré de la profundidad de su sabiduría; por una gran enmienda de mis costumbres, me di cuenta de la bondad de su mansedumbre; por la reforma y la renovación de mi mente y de mi espíritu, ${ }^{37}$ es decir, de mi hombre interior, percibí de alguna manera la belleza de su hermosura; y considerando todas estas cosas a la vez, quedé asombrado de su inmensa grandeza. Pero, cuando el Verbo se aleja, todo esto, empieza a inmovilizarse, y por una especie de languidez a convertirse en pesado y frío, como si a una olla que está hirviendo la retiras del fuego. $Y$ por esta señal clara para mí de su partida, mi alma queda inevitablemente triste, ${ }^{38}$ hasta que vuelve de nuevo, y, como de costumbre, calienta mi corazón dentro de mí, lo cual es un indicio de su regreso». ${ }^{39}$

Para san Bernardo, por tanto, las visitas del Verbo juegan un papel fundamental en la vida de fe: es por medio de la alternancia de presencias y ausencias, y por la variedad de experiencias espirituales, que la persona progresa en la vida espiritual: «Con estas continuas alternativas de las visitas de la gracia y las pruebas de la tentación, [el alma Esposa] va progresando en la escuela de la virtud. La visita de la gracia le impide desfallecer y la tentación la aleja de la soberbia $»^{40}$. Esto mismo es lo que constata Gertrudis en su propia vida.

\section{La Morada}

«Escogiste como aposento de tu hospedaje el domicilio de mi pobreza -dice Gertrudis al Señor-. Pero yo, hospedera degenera-

35 Cf. Ef 1,13 .

36 Cf. Sal 18,13.

37 Cf. Ef 4,23

38 Cf. Sal 41,$6 ; 42,5$.

39 San Bernardo, SC 74, 6 y 7; en: Id., Sermones sobre el Cantar... 468-469.

40 ld., De Diversis 3,1; en: Id., Obras Completas de, Tomo VI, edición preparada por los monjes cistercienses de España (Madrid: BAC, 1988), 61. 
da y descuidadísima, fui negligente en cuidar tu bienestar». ${ }^{41} \mathrm{Ya}$ hemos escuchado que Gertrudis recibió la gracia de la habitación permanente del Señor a su corazón, entre la Pascua y la Ascensión del mismo año de su conversión, 1281. El modo en que tuvo lugar esta gracia fue muy simple. Gertrudis había estado meditando y deseando este don durante todo ese día:

«Tú, Dios mío, ... me enseñaste que, si te devolviera agradecida como fluye el agua, el torrente de tus gracias; si creciera en la práctica de las virtudes, como crecen los árboles, y floreciera con el verdor de las buenas obras; más aún, si despreciando las cosas de la tierra, me lanzara en raudo vuelo, por el deseo, a las cosas celestiales, como las palomas y, alejados como ellas mis sentidos corporales del tumulto exterior, me entregara totalmente a ti con mi pensamiento, entonces, te presentaría mi corazón como amenísima morada de tus delicias»). ${ }^{42}$

Al retirarse a su lecho por la noche, ocurrió lo siguiente:

«De repente me vino a la memoria aquel lugar evangélico: "El que me ama guardará mi palabra, mi Padre le amará, vendremos a él y haremos morada en él" ${ }^{\prime \prime}{ }^{33}$ Al punto mi corazón de barro sintió tu venida y tu presencia .... Desde aquel instante te entregaste a mí, unas veces más benigno, otras más severo, según lo requería la enmienda o negligencia de mi vida». ${ }^{44}$

Se trata de una palabra sustancial que produjo su efecto inmediato en Gertrudis, sin formación de imágenes. Tres son los efectos principales de esta gracia: experiencia, permanencia y fruición de la presencia interior del Señor. Aunque Dios siempre está presente a la persona cristiana en estado de gracia, ordinariamente accedemos a esta realidad por la fe, no por la experiencia sensible. Poder experimentarla, es un efecto de la gracia mística. Gertrudis sintió y comprendió (sensit vel cognovi) que el Señor entraba en su corazón para morar en él. En segundo lugar, la presencia del Señor al corazón de Gertrudis es estable, permanente. Eso no significa que

41 Santa Gertrudis, L II 23,1 7: en MTD I, 208.

42 lbid., 3,1: en MTD I, 139-140.

43 Cf. Jn 14,23.

44 Santa Gertrudis, L II 3,2: en MTD I, 140. 
ella tuviera una consciencia actual ininterrumpida de esta presencia divina, lo cual no es humanamente posible; sino más bien, tenía una consciencia latente, residual, como en el fondo de su corazón, que, al actualizarse en momentos determinados, se revelaba como presencia continua:

«Aunque divagara en mis pensamientos y me deleitase en los peligros,
cuando, desgraciadamente, después de horas, de días y lo que aún, ;oh do-
lor!, temo, después de semanas, volvía a mi corazón, siempre advertí en él
que, ni por un instante, te has apartado de mí hasta el presente, desde aque-
lla hora de la que hace ya nueve años, salvo una vez durante once días...
por una conversación mundana». ${ }^{45}$

Por eso pide al Señor que le conceda la vigilancia del corazón, para poder estar más atenta a su presencia en ella: «Que en adelante me encuentres tan centrada en ti, como tú te haces presente en mí».46

«Para que cuando me ocupe en las cosas exteriores para utilidad del prójimo, me entregue a ellas con medida, y una vez realizadas lo mejor posible para tu alabanza, vuelva a ti en lo más íntimo de mi ser, como las aguas impetuosas se precipitan hacia lo profundo sin obstáculo alguno». ${ }^{47}$

En tercer lugar, la inhabitación divina le permite la delectación espiritual: el fruto de la unión mística es la fruición de Dios. Gertrudis lo señala con expresiones que evocan el deleite del gusto y del tacto. En el siguiente texto, la imagen es la de una mesa con manjares deleitosos, variados y abundantes:

«Imposible explicar con palabras cuántos y cuán numerosos bienes, dignos de todo encomio me has concedido; entre ellos el haber hecho aún más saludable tu presencia en mí. Concédeme, dispensador de todos los dones, ofrecerte por ello, en humilde gratitud, un digno sacrificio de alabanza. Sobre todo, por haberte preparado en mi corazón, con tu beneplácito y el mío, tan encantadora morada. No he leído u oído que, en el templo de Salomón o en el palacio de Asuero, hubiera algo preferible a las delicias que por tu gracia conozco, preparaste tú mismo para ti, en lo más íntimo de mi ser. Con ellas 
me concediste a mí indignísima, una fruición contigo como la tiene la reina con el rey». ${ }^{48}$

Como deja ver el pasaje recién citado, la inhabitación esponsal es recíproca: es presencia mutua. Es un don que pide el consentimiento libre de Gertrudis y es mutuamente deleitable, es decir que el Señor mismo recibe deleite de esta gracia.

Gertrudis distingue además otros efectos colaterales de la morada permanente del Señor a su corazón:

- Es puro don divino: «Te dignaste concederme, sin mérito propio, la alegría de tu saludable presencia, que permanece hasta el presente». ${ }^{49}$ «He de confesar con sinceridad que, aunque la diligentísima enmienda a la que alguna vez llegué, aunque por un momento, se prolongara toda mi vida, jamás hubiera merecido una manifestación tuya». ${ }^{50}$

- Esta gracia permaneció en ella a pesar de su debilidad y pecado: «Aunque divagara en mis pensamientos y me deleitase en los peligrosos, cuando desgraciadamente después de horas, de días y lo que aún ... temo, después de semanas, volvía a mi corazón, siempre advertí en él que, ni por un instante, te has apartado de mí». ${ }^{51}$

- Esta gracia le descubre a Gertrudis la indignidad de su corazón: se ve a sí misma como «sentina de extrema vileza, que tú, de inconmensurable dignidad, elegiste para morar en ella».52

- Esta gracia mueve a Gertrudis a una humildad profunda y a la ofrenda de sí misma al Señor: "Concédeme, dispensador de todos los dones, ofrecerte por ello en humilde gratitud, un digno sacrificio de alabanza». ${ }^{53}$ 
- De la experiencia de la magnitud del don y de su debilidad, se sigue una pedagogía del Señor para con ella: «Tu gran ternura me lleva a pensar, con frecuencia, que te muestras más turbado que airado por mis pecados, $y$ das paso a la virtud de tu paciencia, para soportar con magnanimidad mis faltas». ${ }^{54}$

- Ella saca experiencia de sus faltas y errores, para aprender a guardar su corazón vuelto hacia la presencia del Señor: "para que cuando me ocupe en las cosas exteriores para utilidad del prójimo, me entregue a ellas con medida; y, una vez realizadas lo mejor posible para tu alabanza, vuelva a ti en lo más íntimo de mi ser.» ${ }^{55}$

Como dijimos más arriba, san Bernardo prefiere hablar de visitas, más que de morada permanente, para subrayar la alternancia de la presencia y ausencia del Verbo al alma. Sin embargo, la noción de morada no le es ajena. Cuando la Redactrix, en el Libro I del Legatus, quiere fundamentar su afirmación de que el Señor eligió tener su morada estable en el corazón de Gertrudis, transcribe amplias porciones de un texto de san Bernardo, en el cual se compara el alma del justo con un cielo espiritual, donde Dios viene a habitar. Nos dice la Redactrix:

«Mostraré según mis posibilidades, que ésta [Gertrudis], como he dicho más arriba, es una de esas almas dichosas que, según san Bernardo, escogió Dios como morada suya .... Expondré lo que durante largos años pude descubrir en ella, a través de una amistad espiritual. Dice frecuentemente san Bernardo que el entendimiento es un cielo, es decir, que el alma bienaventurada en la que Dios se digna morar debe tener la belleza de las virtudes, como el ornato del sol, la luna y las estrellas. Así pues, manifestaré brevemente según mi capacidad, la irradiación de aquellas virtudes que esta alma proyectaba desde sí misma, para que quede fuera de toda duda, que el Señor de las virtudes había puesto su morada en lo más profundo de su corazón, al haberla adornado exteriormente de manera tan maravillosa, con la belleza de astros tan refulgentes». ${ }^{56}$ 


\section{Luego la Redactrix cita partes del Sermón 27 de san Bernardo sobre el Cantar de los Cantares: ${ }^{57}$}

«Pienso que el alma santa es celeste no sólo por su origen. Puede llamarse cielo por imitar la vida celeste, ya que vive como ciudadana del cielo. ${ }^{58}$ Por eso dice la Sabiduría: "El alma del justo es trono de la sabiduría" ${ }^{59}$ Y nuevamente: "El cielo es mi trono". ${ }^{60} \mathrm{Si}$ se concibe a Dios como espíritu, no se dudará en asignarle un trono espiritual. Me confirma esta interpretación aquella promesa de la Verdad: "A él -es decir, al hombre santo-, vendremos [mi Padre y yo] y haremos nuestra morada en él" ${ }^{\prime 61}$ Pienso que el Profeta no se refería a otro cuando escribía: "Tú habitas en el santuario, esperanza de Israel". ${ }^{62}$ Y el Apóstol dice claramente que "Cristo habita por la fe en nuestros corazones ${ }^{\prime 63}{ }_{\gg .}{ }^{64}$

«Verdaderamente suspiro ... por aquellos bienaventurados de los que se dice: "Habitaré entre ellos y caminaré en medio de ellos". ${ }^{65}$ ¡Qué dilatada está esa alma, qué prerrogativa la de sus méritos, qué dignidad acoger dentro de sí la presencia divina y ser capaz de contenerla! ¿Y qué será el alma que cuenta con espaciosas galerías a disposición de su majestad? Crece hasta formar un templo santo para el Señor. ${ }^{66}$ La magnitud del alma se mide por la medida del amor que tiene. ${ }^{67}$ Así pues el alma santa es un cielo, en el que el sol es su entendimiento; la luna, su fe; las estrellas, sus virtudes. Dicho de otro modo: el sol es la justicia o el celo de un amor ardiente; y la luna la continencia. No ha de maravillarnos, si el Señor Jesús mora con tanto gusto en este cielo, que, como dijo, no lo creó simplemente como los demás, sino que luchó para adquirirlo, se entregó a la muerte para redimirlo. Por eso, después de tan intenso trabajo se comprometió con un voto: "Esta es mi mansión por siempre; aquí vivirée", ${ }^{\prime 6}$ etc. $\rangle^{69}$

57 Las citas son bastante fieles al texto original de san Bernardo, pero extractadas y ordenadas de modo libre por la Redactrix.

$58 \mathrm{Cf}$. Flp $3,20$.

59 Cf. Pr 12,23 LXX.

$60 \mathrm{Cf}$. Is 66,1 .

$61 \mathrm{Cf} . \mathrm{Jn} 14,23$.

62 Cf. Sal 21,4 .

$63 \mathrm{Cf}$. Ef 3,17

64 Santa Gertrudis, L I 5,1: en MTD I, 82-83; Texto formado con diversos extractos de: San Bernardo, SC 27,8; cf. Id., Sermones sobre el Cantar... 190-191.

65 Cf. 2 Co $6,16$.

$66 \mathrm{Cf}$. Ef 2,21.

67 Texto formado con diversos extractos de: San Bernardo, SC 27,10; cf. Id., Sermones sobre el Cantar... 192.

68 Cf. Sal 131,14.

69 Santa Gertrudis, L I 5, 1: en MTD I, 83-84. Se trata de una cita tomada de: San Bernardo, SC 27,9 ; cf. Id., Sermones sobre el Cantar.. 192. 
Ahora bien, en el sermón original de san Bernardo hay una porción de texto omitida aquí por la Redactrix, donde el santo enuncia cuáles son las condiciones para recibir la morada estable del Verbo. Valgan estas palabras para nosotros:

\begin{abstract}
«Cierto que esa alma no se ocupa para nada de los negocios del mundo, ni se enreda con los cuidados del siglo; no es esclava de los deleites, ni de los placeres sensuales; no se deja llevar de la curiosidad de saber, ni desea mandar a otros, ni se enorgullece con la superioridad. Es preciso que el alma esté del todo exenta de todos estos vicios, para hacerse asilo y mansión de Dios. Si no, ¿cómo podrá contemplar en quietud su esencia y sus infinitas perfecciones? Ha de estar además libre de odio, de toda envidia y de toda acrimonia, por cuanto la sabiduría no entrará en un alma malévola. Además, ha de crecer y dilatarse, a fin de hacerse capaz de recibir a Dios. Esta dilatación es obra de la caridad». ${ }^{70}$
\end{abstract}

\title{
3. Reflexión final
}

El Catecismo de la Iglesia Católica enseña que la inhabitación de Dios en el corazón de las y los fieles cristianos es una gracia ordinaria infundida por el bautismo, que se conserva mientras dure el estado de gracia. ${ }^{71}$ Lo extraordinario, en el caso de Gertrudis, es la conciencia permanente de esta gracia, recibida gratuitamente y cultivada por medio de una constante atención del corazón. Por eso, la oración colecta propia de su fiesta pide al Señor, para todos los bautizados y bautizadas, «que podamos experimentar con alegría tu presencia y tu acción en nosotros». ${ }^{72}$ Es decir, que lo que santa Gertrudis vivió por don extraordinario de Dios, es una perspectiva abierta para toda persona bautizada, en la medida de su deseo, de su renuncia al mundo y al pecado, y de su diligencia en cultivar la atención a la presencia de Dios y la guarda del corazón.

70 San Bernardo, SC 27,10; en: Id., Sermones sobre el Cantar... 192.

71 Catecismo de la Iglesia Católica N 259-260; en: Conferencia Episcopal Argentina, ed., Catecismo de la Iglesia Católica (Buenos Aires-Madrid: 1993), 71-72. Cf. también N¹265-1266, en: Ibid., 333-334.

72 Cf. nota 2. 
Sumado a ello, la perspectiva esponsal de la vida cristiana -o sea, la posibilidad de trabar una relación personal con Cristo como Esposo- también está abierta a toda persona creyente, a partir del bautismo. Este abordaje relacional y amoroso de la vida espiritual tiene la ventaja de que permite ver las exigencias morales de la vida espiritual, como exigencias propias de la relación amorosa, y, por lo tanto, no como un conjunto de preceptos de mínima, sino como un camino abierto hacia una intimidad y pertenencia mutuas con el Señor, siempre crecientes.

El paradigma esponsal es intrínsecamente femenino, puesto que ubica a la persona creyente como alma esposa en relación con Cristo Esposo y, por lo tanto, fomenta las actitudes espirituales de acogida, receptividad, escucha, contención e intimidad. Este enfoque de la vida espiritual ha sido desarrollado y asumido tanto por santos varones como por santas mujeres, a lo largo de la historia de la espiritualidad, y continúa siendo válido hoy, para creyentes de uno y otro sexo. Es en sí mismo un paradigma inclusivo, de pertenencia mutua. Por si esto fuera poco, la imagen de la inhabitación esponsal de Cristo al alma Esposa, es intrínsecamente inclusiva, porque supone que la persona creyente se piense a sí misma como un «ser habitado,» y a Cristo, como «incluido» dentro de sí. Por lo tanto, esta imagen necesariamente genera un lenguaje inclusivo, para poder ser pensada y comunicada.

En una cultura marcada por la eficacia y la competencia, que descarta a las personas consideradas más débiles e incapaces, el enfoque de la relación con Cristo en clave nupcial y el uso de un lenguaje de intimidad y cercanía con Él, resultan educativos, porque permiten hacer experiencia de la vulnerabilidad propia en la relación amorosa, recibir una aceptación profunda de sí mismo desde la mirada de Cristo, y poner en juego la ternura y la acogida del prójimo, en su complementariedad y diferencia. Estas experiencias de fondo son capitales para el fomento de una cultura del diálogo, cuyo signo distintivo sea la hospitalidad y la inclusión. 


\section{Bibliografía}

Gertrude D’Helfta, Oeuvres Spirituelles, Tomo I, Les Exercices, Sources Chrétiennes Nº127, Paris: Du Cerf, 1967.

- Tomo II: Le Héraut Livres I et II, Sources Chrétiennes $N^{\circ} 139$, Paris: Du Cerf, 1968. --Tomo III: Le Héraut Livre III, Sources Chrétiennes 143, Paris: Du Cerf, 1968.

- Tomo IV: Le Héraut Livre IV, Sources Chrétiennes 255, Paris: Du Cerf, 1978.

—, Tomo V: Le Héraut Livore V, Sources Chretiénnes 331, Paris: Du Cerf, 1986.

Santa Gertrudis de Helfta, Los Ejercicios, Burgos: Monte Carmelo, 2003.

—_ El Mensajero de la Ternura Divina. Experiencia de una mística del siglo XIII, Tomo I: Libros 1-3, Burgos: Monte Carmelo, 2013.

—_El Mensajero de la Ternura Divina. Experiencia de una mística del siglo XIII, Tomo II: Libros 4-5, Burgos: Monte Carmelo, 2013.

Bernardo de Claraval, Sermones sobre el Cantar de los Cantares, Madrid: ed. Monasterio de Sta. María de Oseira, 2000.

—, Obras Completas, Tomo VI, Madrid: BAC, 1988. 